\title{
Analysis of grammatical and stylistic features of translation of English absolute constructions into Russian (based on the 20th-century English-language works of literature)
}

\author{
Yelena Yu. Orekhova - Olga S. Polatovskaya - Mariya V. Badelina
}

DOI: 10.18355/XL.2019.12.03.09

\begin{abstract}
The paper is devoted to the study and analysis of the grammatical and stylistic features of the translation of English absolute constructions into Russian on the material of English-language works of literature of the 20th century. The lack of knowledge on the issue necessitated the study of several works and translations. The work was based on the works of William Saroyan, Anthony Burgess, and John Steinbeck and translated editions of these works. The main approaches to the definition of absolute constructions and absolute phrases in the English language are reviewed; the types of absolute phrases are considered; the functions of absolute constructions, described by different scientists, are described; the grammatical and stylistic features of absolute constructions in the English language are studied; the grammatical and stylistic features of the translation of absolute constructions from English into Russian are analyzed.
\end{abstract}

Key words: absolute construction, absolute phrase, grammatical features, stylistic features, the English language, translation

\section{Introduction}

The relevance of this work is due to the insufficient development of the problem of translating English absolute constructions, that do not have constant equivalents in Russian, in particular, the study of their grammatical and stylistic features, as well as the need for more profound research of absolute constructions in English. Moreover, the presence of the contradictions, concerning the choice of the way of translation, indicates the need for a comprehensive study of the issue. Researchers M.A Belyaeva, V.L. Kaushanskaya, R.L. Kovner, A.L. Pumpyansky, and several other scientists suggest that the use of complex sentences in the translation is reasonable. Ya.I. Retsker, on the contrary, believes that complex sentences should be avoided. Contradictions also arise regarding the grammatical and stylistic features of the translation of English absolute constructions. Their translation into Russian varies from stylistically neutral to highly colored. Neglecting absolute constructions when translating leads to significant inaccuracies and a loss of important shades of meaning. The term "absolute construction" was borrowed from the Latin syntax. As noted by B.A. Ilish, the term "absolute" is used in the original meaning of the Latin word "absolutus", i.e. "liberated", "free", "independent", and has nothing to do with the word opposite to the word "relative" (Ilish, 1965: 269). Defining the term "absolute construction" presents a certain difficulty, explained by a number of reasons: the presence of several other terms in addition to the term "absolute construction," as well as different approaches to the definition of this concept and diversity in the definition of the phenomena it includes.

In the national linguistics, the term "absolute construction" is used by E.M. Gordon, B.A. Ilish, I.P. Krylova and Ya.I. Retsker. V.L. Kaushanskaya, R.L. Kovner, O.N. Kozhevnikova, E.V. Prokofiev, Z.M. Raines, S.E. Skvirskaya, and F.Ya. Tsyrlin prefer the term "absolute phrase." However, K.A. Guzeeva, N.A. Kobrina, E.A. Korneev, and M.I. Ossovskaya uses in their works the term "absolute nominative construction". In the work "Practical grammatical of the English language" T.M. Novitskaya and N.D. Kuchin describe an "independent participial phrase" 
(Novitskaya, Kuchin, 1979.) I.M. Berman also uses the term "independent participial phrase." In the book of L.S. Barkhudarov, "The construction of the simple sentence of the modern English language," the term "absolute predicative phrase" is mentioned (Barkhudarov, 1966).

The analysis of several foreign scientific works demonstrates different approaches to the phenomenon considered. In the grammatical reference book "Longman Grammatical of Spoken and Written English," the term "detached predicative" is used. Although it also refers to the use of the term "absolute construction" (Longman Grammatical of Spoken and Written English, 2004: 137). In the dictionary "Webster's Encyclopedic Unabridged Dictionary of the English Language" (Webster's Encyclopedic Unabridged Dictionary of the English Language, 1989) the term "absolute construction" is given, the same term is used by the American scientists Anne Longknife in the book "The art of styling sentences" (Longknife, 2002) and Gregory Stump in work "Semantic variability of absolute constructions" (Stump, 1985).

The variety of existing terms is partly due to different approaches to determining the range of constructions covered by the concept "absolute." Thus, the definition of "nominative" is because the subject of the absolute construction is in the nominative case. However, this term excludes from the scope of the phenomena covered absolute constructions with a pronoun subject in the objective case. For example,

...as we strode along, I doing my best to keep pace with, and him reading aloud from some political economist or other, he would drag out a handful of nuts and munch them (Stump, 1985: 8).

The definition of "participial" indicates that the core of the construction is exclusively the participle, which is reflected in the definition of the concept being studied. Researcher A.L. Pumpyansky in the textbook "Introduction to the practice of translating scientific and technical literature into English" defines absolute participle as a participle in the function of adverbial modifier (or adverbial participle phrase) with an independent subject (Pumpyansky, 1965: 203).

It should be noted that the use of the definitions "nominative" and "participial" leads to the fact that the phenomenon we are studying is not reflected in its entirety, and the range of constructions covered by the concept of "absolute" is narrowed.

Foreign linguists, like most Russian ones, do not distinguish between the terms "construction" and "phrase"; in some cases, the term "word combination" is used (L.S. Barkhudarov). However, such an approach may cause misunderstanding, because the absolute construction/phrase/word combination will be understood as an independent member of a sentence separately, and an independent member of a sentence with the subject and predicate. According to Ya.I. Retsker, the absolute construction includes an absolute phrase and the main part of the sentence (subject and predicate). Distinguishing between "construction" and "phrase," the scientist notes that only the construction as a whole, and not the absolute phrase separately, can be the subject of consideration and establishment of the certain regularities from the point of view of translation (Retsker, 2007: 106).

In the given article the absolute construction is understood by the authors as an absolute phrase together with the main structure of a sentence, and an absolute phrase is understood as an extended member of a sentence with the secondary predication (Retsker, 2007: 86).

The definition of the term "absolute construction" presents a certain problem due to the difficulty of determining the range of phenomena it includes. In the works of Russian and foreign linguists, there are often classifications of "absolute constructions," however, as mentioned above, in this work the concepts of "absolute construction" and "absolute phrase" are distinguished. It is possible to speak about the diversity of types of absolute phrases, which are a part of absolute constructions, but

XLinguae, Volume 12, Issue 3, June 2019, ISSN 1337-8384, eISSN 2453-711X 
talking about the typology of absolute constructions would not be appropriate, because the absolute construction includes not only an independent phrase with the secondary predication, but also the main sentence with the subject and predicate, so that there can be a numerous number of the types of absolute constructions.

There is no consensus regarding the classification of absolute phrases. Different scientists suggest different classifications. Several linguists, considering absolute constructions to be an independent phrase with the participle, distinguish only participial types. So, I.M. Berman considers only one type - the participial phrase (Berman, 1993). T.M. Novitskaya and N.D. Kuchin single out the participial phrase and the participial phrase with the preposition with (Novitskaya, Kuchin, 1979). According to the classification of A.L. Pumpyansky, it is necessary to single out the participial phrase, the participial phrase with the preposition with, the participial phrase with the preposition with and missed being (Pumpyansky, 1965: 207). V.L.

Kaushanskaya, R.L. Kovner, O.N. Kozhevnikova single out four types:

- nominative participial absolute construction;

- prepositional participial absolute construction;

- nominative absolute construction;

- prepositional absolute construction (Kaushanskaya, 1963).

Researcher V.G. Prozorov also considers various types of constructions:

- nominative participial absolute construction: Carol laughed, her eyes sparkling attractively;

- nominative non-participial absolute construction: Marissa walked toward the policeman, all eyes upon her;

- $\quad$ subjectless-participial absolute construction: At first, being little accustomed to learn by heart, the lessons appeared to me both long and difficult;

- absolute construction with the preposition "with": With you for a friend, they shouldn't worry (Prozorov, 1998).

Ya.I. Retsker, distinguishing phrases and constructions, singles out the following types of phrases:

- $\quad$ subject-participial, where the predicative member can be in the form of the first or second participle: No objection arising from any quarter, this plan was adopted;

- $\quad$ subject-nominal where predicative member can be a noun, adjective or a noun with a preposition: His first shot a failure, Dyke fired again;

- $\quad$ subject-adverbial, the predicative member of which is the adverb: The tolling over, the head of the family thrust his hands into the great tail-pockets of his great blue coat;

- $\quad$ subject-infinitive in which the predicative member is in the form of the infinitive:

Such was Bruyan percent at the age of twenty-six, his wisdom-teeth to cut (Retsker, 2007).

Researcher Retsker emphasizes that all the above types of absolute phrases can be introduced with a preposition (most often with). So these phrases are called a "prepositional absolute" by the scientist.

Ya.I. Retsker also identifies absolute constructions with grammatical discontinuity (anacoluthon) in which the subject of an absolute phrase is not expressed, and the predicative part is in the form of Participle I or Participle II, the main part of the sentence only indicates the subject of an absolute phrase. For example,

Being a coward, his brutality was of a cowardly order (Retsker, 2007: 25).

It is obvious that the intended subject of an absolute phrase is a noun in the third person singular, as indicated by the subject of the main structure of the sentence - "his brutality." However, even though the subject referred to in the absolute phrase and the main structure is the same, the subjects are different. In the first case, it is " $h e$ " in the second - "his "brutality." 
American scientist Gregory Stump identifies "the nominative absolute construction" and "the augmented absolute construction." Describing the first type, he writes about the existence of absolute constructions with a pronoun subject in the objective case. By augmented absolute constructions, he understands absolute constructions with the preposition:

\section{With the children asleep, Mary watched TV (Sweet, 1924).}

Taking into consideration the fact that the limitation of absolute phrases only by the participial types does not reflect the phenomenon under study as a whole, and the choice of a nominative type of a phrase with a pronoun subject in the object case, we consider the classification, proposed by Ya.I. Retsker, the most complete, and will rely on it in the further analysis of absolute constructions in the English-language literary works.

The study of the scientific papers on the problem shows that there is no single opinion concerning the functions of absolute constructions. Different researchers distinguish different functions. B.A. Ilish singles out the function of attendant circumstances, A.L. Pumpyansky writes about two functions: the function of attendant circumstances and the defining function. L.S. Barkhudarov and D.A. Shteling distinguish two functions of absolute constructions: the function of dangling modifier and the defining function. M.A. Belyaeva identifies three functions: the function of an adverbial modifier of time, cause, and condition.

The authors of the textbook "Grammatical of the English language" V.L. Kaushanskaya, R.L. Kovner, O.N. Kozhevnikova, E.V. Prokofiev, Z.M. Raines, S.E. Skvirskaya, F.Ya. Tsyrlin describe four functions: the temporary function, the conditional function, the causal function, the function of attendant circumstances.

In order to analyze the grammatical and stylistic features of the translation of English absolute constructions into Russian, we studied the grammatical and stylistic features of absolute constructions in the English language.

From the grammatical aspect, foreign grammarians often point to one significant feature - the lack of grammatical connection between an absolute phrase and the parts of the main sentence (Ann Longknife, 2002).

Gregory Stump focuses on the logical connection, arguing that the logical connection of an absolute phrase with the rest part of the sentence is not grammatically revealed, but nothing is said about the absence of the grammatical connection in his work.

Ya.I. Retsker cites the opinion of a number of foreign scientists who interpret the concept under study in different ways. Grammarian William Burke writes that the absolute construction appears as an adverbial in the sentence and gives the examples (the absolute phrase is replaced by an adverbial clause of cause) to prove his position. For example,

The guide being gone, the trip was postponed = The trip was postponed because the guide being gone (Retsker, 1953: 9).

However, according to Ya.I. Retsker, the replacement of one grammatical structure by another cannot serve as an argument in favor of their identity or equivalence. According to American scientist George Curme, the absolute construction is an elliptical sentence (Curme, 1966.). However, Ya.I. Retsker, citing the words of the Russian scientist A.A. Potebnya, disposes this approach and argues that a piece of speech that does not contain a personal verb, even if omitted, is not a sentence, but only a part of it.

According to Retsker's opinion, "the absence of a grammatical connection between an absolute phrase and the main part of a sentence is not at all a grammatical feature of the absolute construction. Nor it is a logical connection between them. After all, there is a logical connection between independent, standing alongside sentences" (Retsker, 1953: 21).

XLinguae, Volume 12, Issue 3, June 2019, ISSN 1337-8384, eISSN 2453-711X 
In his opinion, the grammatical connection between an absolute phrase and the main part of a sentence exists, and the essence of the absolute construction consists in a special form of this grammatical connection, which Ya.I. Retsker, referring to the work of A.A. Potebnya, calls "free adjunction." A free adjunction, characterizing an absolute construction, is distinguished by firm word order, incompleteness of intonation, and semantic and intonational dependence on the main part of the sentence, as well as internal secondary predication. Relations between the parts of a sentence with secondary predication are close to the relations between the subject and predicate but are characterized by the absence of a personal verb (Potebnya, 1958).

It should be noted that instead of the term "secondary predicativity," introduced by Professor G.N. Vorontsova, the term "secondary predication" or "incomplete predication" can be found more and more often (Ya.I. Retsker). In this paper, we use the term "predicativity" and rely on the work of A.A. Kamynina "About semipredicative constructions in a simple sentence", which says that "predicativity " as a grammatical concept must be distinguished from predication - the mental act, consisting in combination of two concepts with subject-predicate connection, the relation of the determined and determining (Kamynina,1974: 20).

predicativity of an absolute phrase is closely related to firm word order. Consider the following example:

All our savings gone, we started looking for jobs (Stump, 1985: 5).

With a different word order, predicativity is lost, the one-term combination "all our gone savings" is obtained, in which only the subject "savings" is present, complemented by definition "gone." And yet, according to Retsker's opinion, the presence of predicativity in an absolute phrase does not allow to equal an absolute phrase and sentence, because "a participle or other part of speech in the function of an absolute phrase predicate cannot be equal in its predicativity with a personal verb, showing the categories of tense, mood, type, number, person" (Retsker, 1953: 28).

Nevertheless, American scientist Gregory Stump writes about the presence of some categories of personal verbs in absolute phrases: voice and aspect, and gives the following examples:

The eggs and vermiculate are placed in an earthen vessel, the eggs just touching each other, in case there is some inter-egg communication at hatching time (Stump, 1985: 9).

Communist Party leader Edward Gierek, his power battered by striking workers and a corruption scandal, was ousted from office today and replaced by Politburo member Stanislaw Kania, a surprise choice (Stump, 1985: 9).

According to Gregory Stump, in the first sentence, the absolute phrase is in the active voice, while the second one is in passive. The following sentences are examples of the perfective aspect, the perfective continuous aspect, and the continuous aspect:

The Arch has encouraged some new building downtown - the old downtown that was presumably designed to anchor having drifted out into the county by the time the Arch was completed (Stump, 1985: 10) (perfective aspect).

John decided to see a doctor, his health having been steadily deteriorating (Sweet, 1924: 10) (perfective continuous aspect).

On the one side there was that vinegary woman, pocking her head forward like an angry hen, on the other, Daphne Wing, her eyes rounder and rounder, her cheeks redder and redder... (Retsker, 1953: 21) (continuous aspect).

Gregory Stump also writes that absolute phrases can deliver the meaning of time, which is relative, that is, dependent on the events of the main part of the sentence. An absolute phrase can deliver action, simultaneous with an action that is denoted by a verb-predicate, as well as a preceding or subsequent action. For example, 
The bus being crowded, James had to stand (Stump, 1985: 17). (simultaneity).

My task having been finished, I went to bed (Stump, 1985: 14) (precedence).

The absolute phrase has its own subject and is not connected with the sentence by the function word (Hornby, 2005: 5). However, according to Ya.I. Retsker, it "always has a logical correlation with one of the main parts of the main sentence or with the content of the main sentence as a whole" (Retsker, 2007: 107). The nature of the semantic relation can be quite diverse. According to Ya.I. Retsker, "the absolute construction is characterized by a complex connection between phrase and sentence as a whole." This means that between two actions, two types of semantic connection can be realized simultaneously: temporal and causal, temporal and conditional, temporal and concessive" (Retsker, 1981: 68). The following sentence is given as an example:

The agenda being exhausted, the sitting was closed (Retsker, 1981: 68).

The absolute phrase "The agenda being exhausted" can have in this case both a temporary and a causal meaning. In fact, as Retsker states, "the feature of the absolute construction is that the nature of the semantic connection of the phrase with the main sentence remains unrevealed" (Retsker, 1981: 107). This is due to the intention of the author. After all, if the author wanted the reader to determine the nature of this connection, he would use another syntactic means of expressing his thoughts, for example, the adverbial modifier of time or reason.

V.N. Komissarov also considers absolute construction as a construction with a complex meaning. According to the scientist, the complex meaning of the absolute construction combines several adverbial relations. "However, in a particular statement, one or two types of such relations (temporal, causal, concessive, conditional, etc.) can be in the first place, which allows equating the meaning of the corresponding Russian construction to the meaning of the absolute phrase" (Komissarov, 2000: 187).

When considering the stylistic features of absolute constructions in the English language, we also relied on the works of Ya.I. Retsker and analyzed absolute constructions from stylistic (that is, according to the genres of speech) and expressive aspects.

The absolute English construction is a grammatical tool used to simplify the construction of the sentence (Isakova, 2003). Authors use absolute constructions to avoid an abundance of subordinate clauses. That is why the use of absolute constructions is characteristic of scientific and technical texts, as well as the official language of government acts, legal documents, court rulings, etc. The dictionary "Longman Guide to English Usage" states that "the use of absolute constructions comes to very formal situations except several fixed expressions typical of colloquial speech. In addition to a few fixed expressions (such as "weather permitting" and "present company expected"), absolute constructions are used in very formal contexts" (Longman Guide to English Usage. London: Longman, 1988: 6). However, absolute constructions are also found in the texts of fiction.

On the one hand, their use, in this case, may be due to the need to simplify and diversify the construction of the sentence. On the other hand, the fact that the grammatical feature of the absolute construction itself is the heterogeneous construction of the parts of the sentence and the absence of the subject in the absolute phrase is perceived as syntactic contrast and attracts readers' attention, cannot be denied. That is why the absolute construction, used in works of art, can be expressive, attract attention, and emphasize a certain author's idea.

Considering the style of speech, regarding the use of absolute constructions, foreign and Russian scientists agree that the question of the expressiveness of absolute constructions is problematic. The fact is that in the works of Russian scientists,

XLinguae, Volume 12, Issue 3, June 2019, ISSN 1337-8384, eISSN 2453-711X 
studied by us, the expressive meaning of absolute constructions is considered only in the works of Ya.I. Retsker. Among foreign scientists, the English linguist Henry Sweet was engaged in the study of absolute constructions. However, in his fundamental work on the grammatical "A New English Grammatical," he does not consider the expressive features of absolute constructions and gives only a brief mention of the functional style for which absolute constructions are not characteristic. The absolute participial construction is not only typical of the spoken style but is also perceived by many as uncharacteristic for the English language in general. Therefore it should also be avoided in writing (Sweet, 1924: 124). Otto Jespersen, on the contrary, asserts that in English, this construction also occurs quite often (Jespersen, 1958: 114), although the researcher confirms that colloquial speech is not typical for absolute constructions. Among the works of foreign authors, it is necessary to mention the book "Rhetorical Grammatical" by Professor Martha Kolln. The scientist mentions the expressive use of the absolute construction and writes that the absolute construction focuses on the idea of the whole sentence (Kolln, 1996: 200).

Ya. I. Retsker differentiates expressive hues, expressed by the absolute construction, and enumerates several instances of the expressive use of the absolute design: to strengthen the dynamics of the action, to convey the equanimity of the tone, to convey the irony, to clarify the details of the environment of the action. At the same time, the researcher notes that these expressive properties can be combined with each other within the framework of one absolute construction and they cannot always be clearly distinguished (Retsker, 2007: 114).

As a means of strengthening the dynamics of action, non-participial absolute phrases are usually used:

I'll show you how they dance in my village, feet upon the ceiling (Retsker, 1953: 180).

However, participial phrases can also have this function:

Onwards they came, banners flying, dogs barking, cymbals crashing, the band blaring out the hymn... (Retsker, 1953: 181).

The traditional use of absolute constructions in official documentation could not but imposes a certain shade of restraint and dryness on this construction. Therefore, its use is obvious to underline the passionless tone of the narrative. For example, absolute constructions help to preserve the calmness of tone in Edgar Poe's detective stories:

... but at the first puff both our masts went by the board as if they had been sawed off - the mainmast taking with it my youngest brother, who had lashed himself to it for safety (Retsker, 1953: 184).

In the work "Roundabout Papers" by William Thackeray there are absolute constructions of an ironic nature. For example, describing a woman showing her beard in a German resort, Thackeray ironically remarks:

(Retsker, 1953: 190).

The beard having done its day work, she puts it away on a handkerchief

In the function of detailing, the absolute construction specifies the details of the situation, posture, manners, and appearance of the characters. In this function, the absolute construction, as a rule, specifies not permanent signs, but temporary ones. For example:

He came into the room, his face red of shame (Retsker, 2007: 120).

Often, the absolute construction is used to highlight the most important element of the utterance. Consider the following example:

In the car, with Dick driving, the followed the little promontories of the lake, catching the burn of light and water in the windshield, tunneling through cascades of ever green (Retsker, 2007: 121).

In this example, the absolute phrase is far from a secondary fact, which is especially evident in the translation, where this circumstance is placed in the main sentence: 
Дик вел машину вдоль берега озера, по шоссе, огибавшему каждый мысок, и она то ныряла в зеленый древесный туннель, то опять выезжала на открытое место, подставляя ветровое стекло водяным брызгам и солниу (Retsker, 1953: 121).

Ya.I. Retsker also admits that the expressive meaning of the construction can be intensified by the logical diversity of the absolute phrase and the main construction of the sentence (Retsker, 1953: 177).

In his work "The semantic variability of absolute constructions," Gregory Stump notes that absolute phrases with a pronoun subject are perceived by the Englishspeaking population as more formal than phrases with another kind of subject (that is, for example, with a noun subject).

\section{Methodology}

In the given article, modern methodology of scientific research, including a set of theoretical and empiric research methods, is used. For the successful completion of our research, analysis, and synthesis of the ideas and the results of linguistic research on the studied problem were employed. Different resources were used, such as dictionaries, fiction books, scientific and popular articles, Internet resources. The study and analysis of scientific sources and methodological literature made it possible to summarize ideas on the grammatical and stylistic features of the translation of absolute constructions from English to Russian. The approaches to the definition of absolute constructions are considered; the grammatical and stylistic features of the translation of the absolute constructions, identified in the studied works, are analyzed. The comparative analysis and the method of statistical calculations were used in a comparative study of the absolute constructions, found in the works of William Saroyan, Anthony Burgess and John Steinbeck, and their translations into Russian.

\section{Results and discussions}

In order analyze the grammatical and stylistic features of the translation of English absolute constructions into Russian, we chose the original texts of 60 stories by William Saroyan, Anthony Burgess novel "A Clockwork Orange" and John Steinbeck novels "The Grapes of Wrath" and "The Winter of our Discontent." The researched works belong to different literary genres and directions. Thus, the studied works by W. Saroyan are stories, and the works of A. Burgess and J. Steinbeck are novels. The stories of W. Saroyan are realistic works, the works of J. Steinbeck are written in the spirit of naturalism, and "A Clockwork Orange" by A. Burgess is a futuristic novel. The research material included 160 absolute constructions, found in the works under study.

A significant number of absolute constructions is found, with one dominant type of connection between the absolute phrase and the main part of the sentence and, consequently, one dominant function of the absolute phrase can be traced. In the given research, we revealed the absolute constructions in the function of attendant circumstances, the function of explanation, the function of cause.

The works are characterized by the predominance of absolute constructions with a phrase in the function of attendant circumstances. It is about $75 \%$ (121 constructions) of the total number of absolute constructions. For example:

She stood at the front of the class with her legs apart...(Saroyan, 1975: 48).

I was in the Wing Chapel, it being Sunday morning, and the prison charlie was govoreeting the Word of the Lord (Burgess, 2000: 63).

In the works of W. Saroyan, E. Burgess and J. Steinbeck absolute constructions in the function of explanation were also found. Their number is $14 \%$ (22 constructions) of the total number of absolute constructions. For example:

XLinguae, Volume 12, Issue 3, June 2019, ISSN 1337-8384, eISSN 2453-711X 
What a stupid world...each person hidden within himself, wanting something and always getting something else, wanting to give something and always giving something else (Saroyan, 1975: 62).

"Good, good, good. I shall pass that on to Himself," this being what he called the Governor (Burgess, 2000: 99).

Absolute constructions in the function of cause were also found in the works under study. Their number is $11 \%$ (17 constructions). For example:

So we got into the waiting auto and I left it to Georgie to take the wheel, me feeling that malenky bit shagged, and we went back to town, running over odd squealing things on the way (Burgess, 2000: 33).

I wanted music very bad this evening, that singing devotchka in the Korova having perhaps started me off (Burgess, 2000: 72).

We analyzed the logical single-subject / multiple-subject nature of the absolute constructions. The number of single-subject absolute constructions is $50 \%$ of the total number of all revealed absolute constructions. For example:

All that they gave me, my brothers, was a crappy starry mirror to look into, and indeed_I was not your handsome young Narrator any longer but a real strack of a sight, my rot swollen and my glazzies all red and my nose bumped a bit also (Saroyan, 2010: 74).

"That is so," he said, his eyebrows like all beetling while he looked down at me (Saroyan, 2010: 99).

The number of multiple-subject absolute constructions is about $44 \%$ of all revealed absolute constructions. For example:

He was a bolshy great burly bastard with a very red litso, but he was very fond of myself, me being young and also now very interested in the big book (Burgess, 2000: 96).

So then it all really started, but in a queer like gentle way, with nobody raising his goloss much (Burgess, 2000: 105).

11 absolute constructions (6\% of the total number of constructions) cannot be referred to either the first or the second group. They are referred to a separate group. For example:

And there I was with the lights switched on, my gulliver throbbing like a

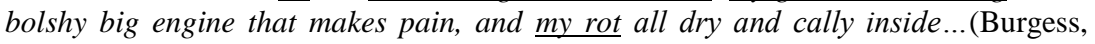
2000: 129).

In the sentence above, the subject of the main part is the pronoun I, and the three absolute phrases, following it, are characterized by the presence of three other subjects: the lights, my guillever, my rot. If the last two subjects logically correlate with the subject I, then the first subject of the absolute construction does not refer to the subject of the main part.

Further on, we studied the absolute constructions considering the position of the absolute phrase to the subject and predicate of the absolute construction. The absolute constructions, identified in the works, were divided into two groups. The first group included the absolute constructions, where the absolute phrase precedes the subject and predicate of the absolute construction. The second group included the absolute constructions, where the absolute phrase follows the subject and predicate. The analysis showed that the first group includes $7.7 \%$ of the total number of constructions. For example:

He waited fearfully, not daring to speak, and the girl walked away from the open window, and with her back phraseed to him, she said, "The trains certainly make a lot of noise, don't they?" (Saroyan, 1975: 145).

But ittying towards it with my glazzies like full on it and my greedy rooker held out, I did not see the milk saucers on the floor... (Burgess, 2000: 75).

The second group includes $86.7 \%$ of all absolute constructions. For example: 
I'm talking about all them heathen people around you in China, and you hungry and dying (Saroyan, 1975: 75).

When the drunkard could no longer hold him and had fallen to the floor, the boy rushed from the room, the knife still in his hand, blood dripping from the blade, his hat gone, his hair mussed, and the sleeve of his coat badly torn (Saroyan, 1975: 179).

It should be noted that there are several absolute constructions that cannot be referred to the first or second group. Consider the following example:

Once long ago, when I lived in a daylight world, the world being too much with me, I would have gone to grass [33, c. 283].

The absolute phrase, in this case, may refer to the sentence "Once long ago when I lived in a daylight world" and the sentence "I would have gone to grass." In the first case, this absolute construction can be classified as construction, where the absolute phrase follows the subject and predicate of the construction, and in the second case, it can be classified as construction, where the absolute phrase precedes the subject and predicate.

main approaches to the definition of absolute constructions and absolute phrases in the English language are reviewed; the types of absolute phrases are considered; the functions of absolute constructions, described by different scientists, are described; the grammatical and stylistic features of absolute constructions in the English language are studied; the grammatical and stylistic features of the translation of absolute constructions from English into Russian are analyzed.

At the next phase of our research, we tried to investigate what factors should be taken into consideration when translating absolute constructions from English into Russian. Let's start from the grammatical aspect. The study of scientific papers shows that while describing the ways of translating English absolute constructions into Russian, some scientists take into consideration the function performed by the absolute phrase. While defining the ways of translating English absolute constructions, Ya.I. Retsker suggests taking into account logical-semantic construction. In his opinion, this could help the translator when translating: "The most important criterion for distinguishing various types of absolute constructions, from the point of view of the translator, is the logical-semantic structure of absolute constructions that is not considered by grammarians" (Retsker, 2007: 112). Depending on the unity or separability of the subject of conjoint (сопряженный) actions, he distinguishes logically one-subject and logically multi-subject absolute constructions. Multi-subject absolute constructions are absolute constructions in which the subject of the absolute phrase and the subject of the main part of the sentence do not coincide. For example:

The muddy fall weather having come on, Martin had pledged his wheel some time since... (Retsker, 2007: 112).

"When the subject of the absolute phrase is a noun denoting a part of the body, posture, clothing, physical manifestation of internal experiences of the subject in the main part, we have one-subject absolute constructions" ... (Retsker, 2007: 113).

Considering the created classification of absolute constructions, Ya.I. Retsker notes that multi-subject absolute constructions can be translated by a compound sentence, conjunctionless compound sentence, and an independent sentence. In addition to the first three ways, logically one-person absolute constructions can also be translated into Russian by a simple sentence with an adverbial participial phrase.

Some scientists, when translating absolute constructions, recommend considering the position of the absolute phrase in the absolute construction. B. A. Ilish suggests taking into consideration the position of the absolute phrase while translating English absolute constructions in his work "The construction of the Modern English Language". "The semantic relations between the absolute construction and the main part of the sentence ... become apparent due to the lexical meaning of words and

XLinguae, Volume 12, Issue 3, June 2019, ISSN 1337-8384, eISSN 2453-711X 
partially the position of the absolute construction in the sentence" (Ilish, 1965: 272). For example:

She had hoped that the war being over, life would gradually resume its old face (Ilish, 1965: 271).

In a few minutes, she rephrased, her eyes shining, her hair still damp (Ilish, 1965: 271).

According to B.A. Ilish, in the first example, the absolute construction has a temporary connection with the main part of the sentence, and in the second, based on the lexical meaning of the words and the position of two absolute phrases, standing after the main part of the sentence, the relation of attendant circumstances arises (Ilish, 1975).

The authors of the textbook "Practical grammatical of the English language" T.M. Novitskaya and N.D. Kuchin also recommend paying attention to the position of the absolute phrase. The absolute phrase, preceding the subject and the predicate of the absolute construction. is usually translated by a subordinate adverbial clause with subordinating conjunctions. For example:

The article being ready, I shall show it to you.

Когда статья будет готова, я покажу ее вам (Novitskaya, Kuchin, 1979: 193).

If the absolute phrase follows the subject and the predicate, the paying construction is translated into Russian by a compound sentence:

On the average some 30 percent of solar energy reaches the land surface each ear, the share being somewhat bidder in southern latitudes and slightly less in northern latitudes.

В среднем ежегодно около 30 процентов солнечной энергии достигает поверхности земли, причем количество солнечной энергии бывает несколько больше в южных широтах и несколько меньше в северных широтах (Novitskaya, Kuchin, 1979: 193).

According to V.N. Komissarov, the translation of absolute constructions as nonequivalent units into Russian is performed using approximate translation and transformational translation. Approximate translation "consists in the use of a grammatical unit of a target language, which partially corresponds to the nonequivalent grammatical unit of the source language in this context" (Komissarov, 2000: 187). The transformational translation "consists in the translation of the meaning of an equivalent unit with the help of one of the grammatical transformations" (Komissarov, 2000: 187), for example, division or integration. It should be noted that different sources offer different terms for the same transformations. I.S. Alekseeva writes about splitting and contraction (compare division and integration) (Alekseeva, 2008); T. A. Kazakova suggests using the terms - splitting and integrating (Kazakova, 2003).

The features of the translation of absolute constructions considered above are based on the explanation of grammatical meaning. However, according to Ya.I. Retsker, stylistic features may remain not translated and not perceived due to their rendering by grammatical means (Retsker, 1953: 227). Therefore, translators sometimes just neglect them, which is wrong.

When conveying the stylistic features of the absolute construction, Ya.I. Retsker recommends paying attention to the type of absolute phrase. So, according to Ya.I. Retsker, the subject-participial phrase with the second participle and the subjectnominal phrase, as a rule, express the dynamics of action. This expressive meaning should be reflected in the translation. Consider the following example from William Thackeray's "The Story of Henry Esmond, Esq.", with the phrase with the second participle:

The King dead then, the Princess Anne was proclaimed by trumpeting heralds all over the town (Retsker, 1953: 264). 
According to the scientist, the translation made by V.I. Shtein lacks dynamics:

Итак, Король скончался, а принщесса Анна была провозглашена королевой по всей столице...при звуках труб скачущих герольдов (Retsker, 1953: 266).

In the translation by E. Kalashnikova, stylistic features are revealed by the translator lexically in a better way:

Итак, тотчас же после смерти короля по всему городу...затрубили герольды,... провозглашая восшествие на престол Анны (Retsker, 1953: 266).

Absolute constructions with combinations "this done," "that done," "this said," "the case being so," etc., which have turned into fixed combinations, are considered to lack stylistic coloring and, as a rule, are translated to Russian by the adverb "then." For example:

I had lit their candles to go upstairs, but Diana had first to give hospitable orders respecting the drivers; this done, both followed me.

Я зажгла свечи, чтобы идти наверх, но Диана сначала распорядилась, чтобы покормили их возницу, затем обе девушки последовали за мной (Retsker, 1953: 266).

The absolute constructions with phrases "this being the case," "such being the case" are characteristic rather of the official style, but can also be found in works of art. Pointing to the reason, they are often translated by the conjunction "therefore."

Such being the case, I felt not a little surprised when he raised his head suddenly from the desk...

Поэтому я очень удивилась, когда он внезапно поднял голову от стола, над которым склонился... (Retsker, 1953: 266).

According to Ya.I. Retsker, absolute phrases with the adverb "over" in the meaning of the adverbial modifier of time also lack stylistic meaning. These phrases are translated by a prepositional phrase: "dinner over" - «после обеда,» "the prayer over" «после молитвы, "lessons over" - «после уроков,» еtc.

However, the scientist emphasizes the unusualness of the noun-subject of the absolute phrase can give the latter a special meaning, expressiveness, which should be reflected in the translation. In such cases, as noted by the scientist, translators usually resort to a complex sentence:

The honeymoon over, I learned my mistake: she was only mad....

Лишь когда прошел медовый месяи, я узнал о своей ошибке: она была сумастедией... (Retsker, 1953: 270).

In this case, the translator uses the "only" particle as a means of expression.

When the absolute construction has an expressive meaning, translators often use a variety of lexical means of expressing expressiveness (interjections, emphatic particles, stylistically colored vocabulary, stylistic techniques, etc.), although the syntactic construction of the sentence should also reflect the expressiveness.

Thus, the dynamics of the action is rendered in the following example, syntactically and lexically: little forward.

She danced, light as a feather, eyes shining, feet flying, her body bent a

Она таниевала с горящими глазами, легкая, как перышко, едва касаясь пола и слегка наклонившись вперед (Retsker, 1953: 272).

The momentum of the action, in this case, is "translated by homogeneous parts in a coordinate conjunctionless sentence, as well as by choosing the shortest possible words" (Retsker, 1953: 266).

The replacement of declarative sentences with absolute phrases by exclamatory or interrogative sentences can also be used to express expressiveness:

Here she comes, her eyes red with weeping. 
А вот и она сама! И с какими красными, заплаканными глазами! (Retsker, 1953: 283).

When translating absolute constructions, Ya.I. Retsker suggests also paying attention to the rhythmic-melodic and intonational features of the original. Thus, the author's somewhat jerky manner of narration can be conveyed by a conjunctionless complex sentence. Moreover, on the contrary, to translation a smooth author syllable, a translator can refuse from a conjunctionless complex sentence and resort to a complex subordination. Consider the example from the work of William Thackeray "Vanity Fair":

Lord Steyne's visits continuing, his own ceased (Retsker, 1953: 261).

The sentence is translated in the following way:

Визитьл лорда Стайна продолжались, его собственные прекратились (Retsker, 1981: 266).

This translation does not match the style of the original since the absolute construction does not have a tint of abruptness. The best way would be to use a complex sentence, as translated by L. Gay:

Так как посещения лорда Стейна продолжались, 느 он прекратил свои визиты к невестке (Retsker, 1953: 262).

Thus, to express the stylistic features of absolute constructions in translation, as a rule, a variety of lexical means are used (interjections, emphatic particles, stylistically colored vocabulary), and stylistic techniques, although the syntactic construction of the sentence can also help to reflect stylistic features.

In the next phase of our research, we studied the dependence of the translation on the function of the absolute phrase, unity or separability of the subject of the action in the absolute phrase and the main part of the sentence, the position of the absolute phrase relative to the subject and predicate in the absolute construction.

It should be noted that all methods for the translation of absolute constructions described above are characteristic of the works under study. Both approximate translation and various transformations are used in the process of translation.

Approximate translation is implemented in the use of compound, conjunctionless complex and complex sentences. For example:

He felt lonely and ill in the empty classroom, all the boys going home... all of them walking along the southern Pacific tracks laughing and playing... (Saroyan, 1975:59].

Compare,

В пустом классе одиноко и невмоготу, все ребята пошли домой, идут сейчас вдоль железной дороги...смеются, играют... (Saroyan, 1988: 177).

With the use of approximate translation, absolute constructions are also translated by simple sentences with participial (rarely) or adverbial participial phrases. For example:

A little bit ahead he saw the high-domed shell of a land turtle, crawling slowly along through the dust, its legs working stiffly and jerkily (Steinbeck, 1962: 17).

Compare,

Он увидел впереди выпукльй панцирь черепахи, медленно и как бы рывками передвигавшей свои неуклюжие ноги (Steinbeck, 1987: 64).

He sat up as if he were in his bed at home, and then, after dreaming with his eyes open for ten minutes, stepped down (Saroyan, 1975: 267).

Дональд выпрямился, как будто сидел на своей кровати дома, а потом, минут десять подремав с открыттыми глазами, слез с ящиков (Saroyan, 1988: с. 239). The transformational translation is also common when translating absolute constructions from English into Russian. As a rule, transformations of division or integration are applied. For example: 
With him was Dr. Branom, all smiling like as though to give me confidence (Burgess, 2000: 123).

Compare,

Рядом с Бродским стоял и доктор Браном с ульгбкой от уха до уха видимо, он так старался меня ободрить (Burgess, 2010: 132).

and he chained me gentle and artistic like on the glazlids, me just closing them up in time (Burgess, 2000: 78).

Compare,

(Burgess, 2010: 54).

.... х хлестнул меня иепью по глазам. Я едва успел их закрыть

It should be noted that sometimes absolute constructions (especially those including several absolute phrases) undergo more complex transformations. Often they are translated with complex syntactic structures (complex sentences of mixed type). For example:

He was angry and ashamed and lonely, but not crying, his right eye black and his lip cut and swollen (Saroyan, 1975: 391).

Он сидел одинокий, пристыюженный и сердитый, и все-таки не плакал, хотя под правым глазом у него был синяк, а верхняя губа была разбита и вспухла (Saroyan, 1988: с. 297).

This sentence is characterized by a subordinate connection, revealed in the use of the subordinate conjunction "though," and a composing connection revealed in the use of the coordinative conjunction "but."

It was in studies revealing that absolute constructions with an absolute phrase in the function of the attendant circumstances, as a rule, are translated by means a conjunctionless complex sentence (36 constructions from 121), a compound sentence (21 constructions from 121), a simple sentence (19 constructions from 121), a simple sentence with an adverbial participial phrase (11 constructions from 121), several simple sentences (9 constructions from 121), a simple sentence with a participle (8 constructions from 121), a complex sentence ( 9 constructions from 121), a mixed complex sentence (8 constructions from 121).

For example:

Now we were the very good malchicks, smiling good evensong to one and all, though these wrinkled old lighters started to get all shook, their veiny old rookers all trembling round their glasses... (Burgess, 2000: 15).

Compare,

Тут мы уже выступали этакими pai-malltshikami, ульљбались, делали благовоспитанный zdrasting, хотя старые вешалки все равно от страха были в отпаде, их узловатые, перевитые венами rukery затряслись... (Burgess, 2010: 12).

And so the autobus to Center, and then the autobus to Kingsley Avenue, the flats of Flatblock 18A being just near (Burgess, 2000: 159).

Compare,

Так что вперед, автобусом до иентра, потом другим автобусом до Кингсли-авеню, а оттуда до нашего квартала рукой подать (Burgess, 2010: 171).

The tenant man stared after it, his rifle in his hand (Steinbeck, 1962: 41).

Compare,

Арендатор смотрел ему вслед с ружьем в руках (Steinbeck, 1987: 55). Absolute constructions with a phrase in the function of explanation, as a rule, are rendered by a conjunctionless complex sentence (45.5\%), a compound sentence $(23 \%)$, or two separate sentences $(18 \%)$, resulting from the division of the structure. For example:

I didn't like that, it being dirty and slobbery...(Burgess, 2000: 30). Compare,

XLinguae, Volume 12, Issue 3, June 2019, ISSN 1337-8384, eISSN 2453-711X 
Такого я не любил - это грязно и неопрятно... (Burgess, 2010: 30).

The house boiled with emotion - Ellen in slow, dripping, juicy tears, Mary tired and flushed with frustration... (Steinbeck, 1962: 226).

Самый воздух в доме был наэлектризован волнением. Эллен проливала тяжелье, медленные, смачные слезы. Compare,

Мэри была вся красная от негодования и усталости (Steinbeck, 1987: 687).

Absolute constructions with a phrase in the function of the adverbial modifier of cause are usually translated as conjunctionless complex sentences (53\%) and complex sentences $(29.5 \%)$. These two ways of translating structures with a phrase of this type are dominant. For example:

And all the time lewdies passed by and viddied all this but minded their own, it being perhaps a common street-sight (Burgess, 2000: 66).

Compare,

То и дело мимо или люди, видели все это, но не совались - надо полагать, такого рода зрелища им давно примелькались (Burgess, 2010: 69).

So then I got real bezoomny and lashed out, though I could not viddy all that horrorshow, there being only this malenky little red light outside on the landing (Burgess, 2000: 105).

Compare,

Ну, тут я стал совсем ьеzитпі и с ходу выдал ему, хоть я и не различал ничего толком, потому что горел только маленький красный свет на площадке (Burgess, 2010: 111).

Further analysis of the grammatical features of the translation of absolute constructions was carried out depending on the logical one-subject/multi-subject nature of constructions. It was found out that the logically one-subject and logically multi-subject absolute constructions are translated by all known methods described above.

The analysis of the absolute constructions also showed that logically one-person absolute constructions can be translated into Russian by a simple sentence with an adverbial participial phrase while translating multi-subject constructions, an adverbial participial phrase is not used. Consider the example of one-subject construction translated by a sentence with an adverbial participial phrase:

"Don't take it like that, son," and my mum just went boo hoo hoo, her litso all screwed up real ugly, and this Joe put his rooker round her again, patting her and going there there there like bezoomny (Burgess, 2000: 165). Compare,

- Не надо так воспринимать это, сын, - сказал отеи, а мать, некрасиво перекосив rot, снова взвыла - УУУУ-УУ-УУУ - и Джо опять обнял ее за плечи, похлопьвая и приговаривая "ну-ну, ну-ну", как bezumni (Burgess, 2010: 177).

Having analyzed the dependence of the ways of translating the considered absolute structures from English into Russian on the position of the absolute phrase, we have not found any significant differences. Thus, both absolute constructions with a phrase, preceding the main composition, and constructions with a phrase after the main part are translated by all using all described methods. An exception is translation by a simple sentence with a participial phrase, found only in constructions with a phrase after the main part. For example:

When Joad heard the truck get under way, gear climbing up to gear and the ground throbbing under the rubber beating of the tires, he stopped and phraseed about and watched it until it disappeared (Steinbeck, 1962: 16).

Compare, 
Усльшиав, что грузовик тронулся с места и, набирая скорость, покатил по шоссе, глухо откликавшемуся на шлепки резиновых шин, Джоуд остановился и проводил его взглядом (Steinbeck, 1987: 33).

Absolute constructions with an absolute phrase, preceding and following the main part, are translated by a complex sentence. For example:

But with project tucked away and gone as a part of me, I saw him now as an object apart - no longer linked with me for good or bad (Steinbeck, 1962: 239).

Compare,

Но сейчас, когда затея моя была запрятана в дальний угол и уже не существовала как часть меня самого, я увидел в этом человеке нечто иное - уже не связанное со мной ни к добру, ни к худу (Steinbeck, 1987: 700).

In the following examples, the absolute constructions with the absolute phrase, preceding (in the first sentence) and following the main part (in the second sentence), are translated as simple sentences by means of integrating transformation:

Even with the wide door open, it was dark in the ends of the car (Steinbeck, 1962: 4521).

Compare,

В углах вагона было темно даже при открытой двери (Steinbeck, 1987: 436)

Around eleven, after the Italian food and wine, we broke up, having all of us had a rather nice time (Saroyan, 1975: 423).

Compare,

Около одиннадиати, после итальянских блюд и вина, мы расстались довольные проведенным временем (Saroyan, 1988: с. 264).

Absolute constructions of both types can be translated into the Russian language by a simple sentence with an adverbial participial phrase:

Face downward...I became one with ants and aphids and sow bugs, no longer a colossus (Steinbeck, 1962: 283).

Compare,

Лежа ничком...бывший великан сливался воедино с муравьями, тлями, букашками (Steinbeck, 1987: 737).

Fifteen feet back from the men the fed cat was sitting, the long gray tail wrapped neatly around the front feet (Steinbeck, 1962: 56).

Compare,

Шагах в пятнадиати от людей, аккуратно обвив хвостом передние лапки, сидела насытившаяся кошка (Steinbeck, 1987: 68).

It should be noted that the expressive use of absolute constructions is characteristic of the works studied. As a rule, absolute constructions are used to clarify the details of the situation. In general, the number of absolute constructions used to clarify the details of the situation is 24 . For example,

Ruthie came near, in her hands two large boxes of Cracker Jack, in her eyes a brooding question, which on a nod or a shake of Ma's head might become tragedy or joyous excitement (Steinbeck, 1962: 453).

In the fiction works under study, there are also constructions, which are characterized by an expressive function of strengthening the dynamics of action. This function is revealed in four absolute constructions. For example,

... and there she was, trembling, her eyes wet and tears coming out of

them, her face in agony, and he was still laughing... (Saroyan, 1975: 64).

Charter boats tied close for boarding passengers, the frantic summer fisherman who pay a price and glut the decks with fish and in the afternoon wonder vaguely what to do with them, sacks and baskets and mountains of porgies and blows

XLinguae, Volume 12, Issue 3, June 2019, ISSN 1337-8384, eISSN 2453-711X 
and blackfish, sea robins, and even slender dogfish, all to be torn up greedily, to die, and to be thrown back for the waiting gulls (Steinbeck, 1962: 218).

Absolute constructions with an expressive function of irony are presented in twice in the works under study. Two constructions can be identified:

It was pretty funny, Harry thinking of retiring at eighteen (Saroyan, 1975:

Tonight was what thy called a worldcast, meaning that the same programme was being viddied by everybody in the world that wanted to, that being mostly the middle aged middle class lewdies (Burgess, 2000: 24).

The expressive meaning of the calm, passionless tone of the narrative is characteristic of one absolute construction:

The tenant sat in his doorway, and the driver thundered his engine and started off, tracks falling and curving, harrows combing, and the phalli of the seeder slipping into the ground (Steinbeck, 1972: 41).

The analysis of the stylistic features of the translation of absolute constructions from English into Russian showed that, when translating 30 absolute constructions, the expressive meaning of the construct was reflected in the translation.

So, when translating one of the constructions used to strengthen the dynamics of the action, the translator uses ellipsis and conjunctionless sentences and tends to use the shortest possible words:

... and there she was, trembling, her eyes wet and tears coming out of them, and her face in agony, and he was still laughing... (Saroyan, 1975: 64).

Compare,

...и вот, пожалуйста - она дрожит, а в глазах слезы, сейчас заплачет, на лице мука, а он все смеется... (Saroyan, 1988: 180).

The expressive significance of the dynamics of the action of the following construction is realized in the use of polysyndeton:

Charter boats tied close for boarding passengers, the frantic summer fisherman who pay a price and glut the decks with fish and in the afternoon wonder vaguely what to do with them, sacks and baskets and mountains of porgies and blows and blackfish, sea robins, and even slender dogfish, all to be torn up greedily, to die, and to be thrown back for the waiting gulls (Steinbeck, 1962: 218).

Compare,

У причалов наемные лодки ожидали пассажиров, одержимых рыболовов-отпускников, которые денег не жалеют, а к кониу дня озираются, не зная, что делать с массой рыбы, завалившей лодку. Полны все мешки, все корзины, громоздятся на дне кучи триглы, морского лещза и морского окуня, и даже мелкой акуль-колючки, и все это задыхается и гибнет и будет выброшено обратно в море, чайкам на съедение (Steinbeck, 1987: 679).

When translating absolute constructions used to convey irony, the translator resorts to nominative sentences:

It was pretty funny, Harry thinking of retiring at eighteen (Saroyan, 1975: $54)$.

\section{Compare,}

Смех один - восемнадцать лет мальчишке, а он на покой собрался

(Saroyan, 1988: 14).

In the following example, the absolute construction is used to express a calm, unimpassioned tone corresponding to the slow movement of the tractor:

The tenant sat in his doorway, and the driver thundered his engine and started off, tracks falling and curving, harrows combing, and the phalli of the seeder slipping into the ground (Steinbeck, 1962: 41).

Compare, 
Арендатор уходил на крыльцо, а тракторист запускал мотор и ехал дальше. За трактором тянулись борозды, железные зубья прочесывали землю, детородные члены сеялки роняли в нее семена (Steinbeck, 1987: 55).

In order not to pad out the sentence, the translator resorted to the transformation of division. Despite the fact that parts of a sentence are connected by asyndeton, the sentence does not sound abruptly; on the contrary, relatively long words give it a certain steadiness.

Emphasization is a common method of delivering the expressive meaning of absolute constructions. Consider the following example:

There was a doddery starry schoolmaster type veck, glasses on and his $\underline{\underline{r o t}}$ open to the cold nochy air (Burgess, 2000: 9). Compare,

Нам попался ободранный starikashka, немощный такой tshelovek в очках, хватающий разинутым hlebalom холодный ночной воздух. (Burgess, 2010: $10)$.

According to the " Explanatory dictionary of the Russian language " by D.N. Ushakov, the word «хлебало» ("hlebalo"), used in the translation, has the mark "colloquial," while the noun "pom (mouth)" is stylistically neutral. The original "starry type veck" (that is, the "old man") is conveyed by the word "old man" ("starikashka"), which has the notation "colloquial" and the meaning of "petderogatory word from the old man."

The following example contains the stylistically neutral verb "want," which is transformed into the verb "жаждать," having, according to the "Explanatory Dictionary" edited by S.I. Ozhegov, mark "high":

The two of them in the empty classroom, naked, together in their loneliness and bewilderment, brother and sister, both of them wanting the same cleanliness and decency of life, both of them wanting to share the truth of the other, and yet, somehow, both of them alien, remote and alone (Saroyan, 1975: 65).

Compare,

Двое в пустом классе, нагие в своем одиночестве и растерянности, брат и сестра, оба жаждут чистоть и честности в жизни, каждый жаждет постичь и разделить правду другого, и почему-то каждый отчужден, отъединен, одинок (Saroyan, 1988:180).

Translations are also characterized by various types of stylistic repetitions. In the following construction anadiplosis is used:

Tonight was what thy called a worldcast, meaning that the same programme was being viddied by everybody in the world that wanted to, that being mostly the middle aged middle class lewdies (Burgess, 2000: 24).

Compare,

В тот день происходило то, что у них называлось всемирным вещанием - одну и ту же программу передавали по всему миру, кому угодно, а угодно главным образом бывало людишкам средних лет и среднего достатка. (Burgess, 2010: 27).

Synonymous repetition is also one of the methods that translators use to achieve the expressiveness of the absolute construction. For example:

There was a doddery starry schoolmaster type veck, glasses on, and his rot open to the cold nochy air (Burgess, 2000: 10).

Compare,

Нам попался ободранный starikashka, немощный такой tshelovek в очках, хватающий разинутым hlebalom холодный ночной воздух (Burgess, 2010: 9).

In this example, the translator resorts to a synonymous repeat of "starikashka" "weak tshelovek."

XLinguae, Volume 12, Issue 3, June 2019, ISSN 1337-8384, eISSN 2453-711X 
Grammatical substitutions at the morphological level can also serve as a means of expression. For example, the use of the present historical time gives a narrative vividness:

Me just walking in through the door and saying: "Here I am, back, a free veck again” (Burgess, 2000: 132).

Compare,

- Вдруг вхожу в дверь и говорю: "Вот и я, явился не запьлился, снова на свободе! " (Burgess, 2010: 141).

A common occurrence in translation is the use of adding transformation. At the same time, different units can be added - nouns, adjectives, particles, etc., which add to the expressional effect. So, in the following examples, translators resorted to adding the adjective "doddery" and the particles "here":

There was a doddery starry schoolmaster type veck, glasses on, and his rot open to the cold nochy air (Burgess, 2010: 10).

Compare,

Нам попался ободранный starikashka, немощный такой tshelovek $в$ очках, хватающий разинутым hlebalom холодный ночной воздух (Burgess, 2010: 9).

In the original, only the adjective "doddery" is present, corresponding to the word "weak." The word "shabby" in the "Explanatory Dictionary of the Russian Language" edited by D.N. Ushakov has the mark "colloquial."

In the next sentence, the particle "here" is used. According to the explanatory dictionary edited by D.N. Ushakov, a particle is placed next to the word the logical stress falls on, for its greater emphasis:

His mother spoke once of using them for fuel, there were so many of them and nobody eating them, but Jim told he wanted them (Saroyan, 1975: 351).

Compare,

Мама как-то сказала, что надо ими камин топить, вот сколько лежит и никто не ест, а Джим сказал, что они ему нужны... (Saroyan, 1988: 340).

Inversion can also serve as a means of achieving expressiveness. For the following example, the inverse of a possessive pronoun is characteristic:

But with project tucked away and gone as a part of me, I saw him now as an object apart - no longer linked with me for good or bad (Steinbeck, 1972: 239).

Compare,

Но сейчас, когда затея моя была запрятана в дальний угол и уже не существовала как часть меня самого, я увидел в этом человеке нечто иное уже не связанное со мной ни к добру, ни кхуду (Steinbeck, 1987: 700).

\section{Conclusion}

In the given article, the concepts of "absolute construction" and "absolute phrase" are distinguished. The absolute construction is considered by the authors as an absolute phrase with the main part of the sentence. An absolute phrase has a certain grammatical and stylistic meaning only together with the main construction, that is, as an absolute construction, and only the construction as a whole it can be the subject of study and the establishment of certain regularities in terms of translation.

It is possible to speak about the diversity of types of absolute phrases, suggested by different scientists. The authors of this study consider the classification proposed by Ya.I. Retsker, the most complete, and rely on it in the analysis of the absolute constructions in English-language works. According to Ya.I. Retsker, there are the following types of phrases: subject-participial, subject-nominal, subject-adverbial, subject-infinitive.

It should be noted that different researchers distinguish different functions of absolute constructions or phrases. They are the function of attendant circumstances, the 
defining function, the function of the dangling modifier, the function of an adverbial modifier of time, cause and condition. Also, some scientists single out temporary, conditional, causal functions.

The study of scientific papers on the problem made it possible to reveal the grammatical and stylistic features of English absolute constructions. The absolute construction is interpreted differently: as an adverbial modifier, an elliptical sentence, or a subordinate expanded part of the sentence with a secondary predicativity. There is a grammatical connection between the absolute phrase and the main part, called "free adjunction." The absolute phrase can perform the function of time, cause, condition, attendant circumstances, or the function of explanation, or be characterized by the presence of a complex relation. Due to the heterogeneous construction of the parts of the sentence and the absence of the subject in the absolute phrase, absolute constructions can have expressive meaning. The expressive functions of the absolute construction are 1) dynamics of the action; 2) calm, passionless narration; 2) irony; 4) clarification of details of the action environment.

In order to analyze the grammatical and stylistic features of the translation of English absolute constructions into Russian, the authors used the original texts of the famous English and American writers: Anthony Burgess ("A Clockwork Orange"), William Saroyan (60 stories) and John Steinbeck ("The Grapes of Wrath" and "The Winter of our Discontent").

The analysis revealed the predominance of absolute constructions with a phrase in the function of attendant circumstances (121 constructions - 75\% of the total number of constructions), the function of explanation (22 constructions - 14\%) and the function of cause (17 constructions - 11\%). The number of logical single-subject / multiplesubject absolute constructions is 80 constructions (50\%), 70 constructions (44\%) and 10 constructions $(6 \%)$ (a separate group), respectively. In the works under study, the predominance of absolute constructions with a phrase, following the main part (139 constructions out of $160-87 \%$ ) is revealed.

The study of the works of literature and their translated editions showed that approximate translation is used in most cases; in some cases, translators resort to transformations. In addition to the most common ways of translating, conjunctionless complex and compound sentences, absolute constructions with a phrase in the function of attendant circumstances are usually translated by simple sentences; constructions with a phrase in the function of explanation are translated by a few simple sentences; constructions with a phrase in the function of the adverbial modifier of cause are translated by means of a complex sentence. It was found out that logically one-subject constructions can be translated by a simple sentence with an adverbial participial phrase, while logically multi-subject absolute constructions are not translated by this way. It was also revealed that absolute constructions with a phrase after the main part can be translated by a simple sentence with a participial phrase.

The analysis of the literary works and their translated editions also showed that 31 absolute constructions have expressive meaning. In most cases, absolute constructions have the expressive meaning of specifying details of the situation ( 24 constructions). Absolute constructions, characterized by an expressive function of strengthening the dynamics of the action, are also found in the works under study (4 constructions), expressing irony ( 2 constructions) and the calm, passionless tone of the narration (1 construction). Among 31 absolute constructions that have an expressive meaning, 25 constructions (80\%) function as attendant circumstances, 6 constructions (20\%) act as explanatory functions. 16 constructions $(51.6 \%)$ are logically multi-subject, 15 constructions (48.4\%) are logically one-subject. In 27 constructions (87\%), the absolute phrase goes after the main construction of the sentence, in 4 constructions (13\%) the absolute phrase is after the main construction. As for the type of absolute

XLinguae, Volume 12, Issue 3, June 2019, ISSN 1337-8384, eISSN 2453-711X 
phrase, 23 constructions (74.2\%) have a subject-participial phrase with the participle I, 7 constructions $(22.6 \%)$ have subject-nominative, 1 construction $(3.2 \%)$ has ea subject-infinitive phrase.

Various means are used to render the stylistic features of absolute constructions: 1) lexical transformations (lexical-semantic substitutions - emphasization); 2) grammatical transformations (grammatical substitutions at the morphological level historical present, at the syntactic level - addition); 3) syntactic construction of the sentence (use of conjunctionless complex sentences); 4) stylistic techniques (inversion, polysyndeton, ellipsis, repetitions - anadiplosis, synonymous repetition).

The results of the analysis suggest a greater expressiveness of absolute constructions with the subject-participial phrase with participle I and subject-nominative phrase, as well as constructions in the explanatory function and the function of the attendant circumstances.

\section{Bibliographic references}

ALEKSEEVA, I.S. 2008. Introduction to Translation Studies: A textbook for students of philological and linguistic faculties of higher educational institutions. - 3rd ed. Saint-Petersburg: Faculty of Philology of St. Petersburg State University; In: Publishing Center "Academy".

BARKHUDAROV, L. S. 1966. The construction of a simple sentence of modern English. Moscow: Vysshaya shkola.

BARKHUDAROV, L.S. - SHTELING, D. A. 1960. English grammar. In: Publishing house of literature in foreign languages.

BELYAEVA, M.A. 1984. English grammar: Study guide. - 7th ed., In: Vysshaya shkola.

BERMAN, I.M. 1993. English grammatical. IN: Higher School. ISBN 5-06-002399-0 BURGESS, A. 2010. Clockwork orange// Translated from English by V. Boshnyak. M.: AST. ISBN: 978-5-17-065004-0

BURGESS, A. 2000. Clockwork Orange. New York: Penguin Modern Classics. ISBN 10: 1856132668

CURME G.O. 1966. English Grammar. The principles and practice of English grammar applied to present-day usage. New York: Barnes and Noble.

English grammatical: studies. 1963. Study guide / V.L. KAUSHANSKAYA, R.L. KOVNER, O.N. KOZHEVNIKOVA et al. Leningrad: Uchpedizdat.

English grammar: Morphology. Syntax: Study guide. 2003 / N.A. KOBRINA, K.A. GUZEEVA, E.A. - KORNEEV, M.I. OSSOVSKAYA. Saint-Petersburg: Soyuz.

Explanatory dictionary of the Russian language. 1996. In: 4 volumes / D. N. USHAKOV. M.: State. publishing house of foreign and national Words.

GORDON, E.M. - KRYLOVA, I.P. 1974. A practical grammar of modern English. In: Vysshaya shkola.

HORNBY A. S. 2005. Oxford advanced learner's dictionary. New York: Oxford university press.

ILISH, B.A. 1965. The structure of modern English (in English). In: Prosveshenie.

ISAKOVA, L.S. 2003. Problems of translating absolute constructions: on the translation of novels and short stories by F. S. Fitzgerald into Russian: dis. can. philol. sciences. - Moscow.

JESPERSEN, O. 1958. The philosophy of grammatical. In: Publishing house of foreign literature.

KAMYNINA, A.A. 1974. About semi-predicative constructions in a simple sentence: Study guide / Moscow State University. In: Moscow University Press.

KAZAKOVA, T.A. 2003. Practical basics of translation. English - Russian: textbook. Saint-Petersburg: Soyuz.

KOLLN, M. 1996. Rhetorical Grammatical: Grammatical Choices, Rhetorical Effects. Boston: Allyn \& Bacon. 
KOMISSAROV, V.N. 2000. Modern translation: a course of lectures. In: ETS.

LONGKNIFE, A. - SUlLIVAN, K. D. 2002. The Art of Styling Sentences: 20 patterns for success. - 4th ed. New York: Barron's. ISBN-10: 9780764121814

Longman Grammatical of Spoken and Written English. London: Longman, 2004. ISBN 10:0582539420

NOVITSKAYA, T. M. - KUCHIN, N. D. 1979. Practical English grammatical: study guide. In: Vysshaya shkola.

OZHEGOV, S. I. - SHVEDOVA, N. Yu. 1996. Explanatory dictionary of the Russian language: 80000 words and phraseological expressions. In: Az.

POTEBNYA, A.A. 1958. From notes on Russian grammar. Vol. I-II. In: 1958.

PROZOROV, V.G. 1998. Fundamentals of the theory and practice of translation from English into Russian. Petrozavodsk: KSU.

PUMPYANSKY, A. L. 1965. Introduction to the practice of translating scientific and technical literature into English. In: Science.

RETSKER, Ya. I. 1953. The stylistic and grammatical meaning of absolute constructions in modern English: dis. can. philol. sciences. Moscow.

RETSKER, Ya.I. 2007. Translation theory and translation practice. Essays on the linguistic theory of translation, Additions, and Comments of D.I. Ermolovich. 3rd ed. In: R. Valent. ISBN:978-5-9907943-0-6

RETSKER, YA. I. 1981. Textbook on translation from English into Russian. In: Foreign languages.

SAROYAN, W. 1975. Selected stories (in English). In: Progress.

SAROYAN, W. 1988. Novel and stories. Joseph Heller. Amendment-22: Novel. Translated from English. In: Rainbow. ISBN: 5-05-002276-2

SAROYAN, W. 2010. My Name is Aram. London: Capuchin Classics.

STEINBECK, J. 1987. The Grapes of Wrath. The Winter of our Discontent. Novels. Translated from English. In: Pravda.

STEINBECK, J. 1962. The Winter of Our Discontent. New York: Bantam books.

STEINBECK, J. 1972. The Grapes of Wrath. New York: Bantam books.

STUMP, GREGORY. 1985. The semantic variability of absolute constructions. Columbus: Kluwer Academic Publishers.

SWEET, H. 1924. A New English Grammatical. London: Oxford University Press.

VORONTSOVA, G.N. 1959. The secondary predicate in English, Foreign languages in school, No. 6, pp. 46-56.

WEBSTER'S ENCYCLOPEDIC UNABRIDGED DICTIONARY OF THE ENGLISH LANGUAGE. 1989. New Jersey: Gramercy Books

Words: 3865

Characters: 77224 (42,90 standard pages)

assoc. prof. Yelena Yu. Orekhova

Department of Foreign Languages

Surgut State University

Surgut, Russia

orehova_eju@surgu.ru

Olga S. Polatovskaya

Department of Linguistics and Interpretation Studies

Surgut State University

Surgut, Russia

ospolatovskaya@mail.ru 
assoc. prof. Mariya V. Badelina

Department of Natural Sciences and Humanities

Tyumen Industrial University

Tyumen, Russia

mvbadelina@mail.ru 